\title{
Od zabytku do dyskursu. 0 kilku źródłach współczesnej definicji dziedzictwa ${ }^{1}$
}

\section{Abstract}

\section{From Monument to Discourse. On a Number of the Sources of the Contemporary Definition of Heritage}

The author shows the contemporary definition of heritage stemming from the concept of the monument and its "extension". Furthermore, he puts it in the context of symbolic exchange, indicating the deeply symbolic dimension of heritage and placing an emphasis on its intangible character. In addition, he associates heritage with the notion of lieux de mémoire, writes about the discursive strategies leading to its invention, juxtaposes heritage with history and connects it with the postmodern "condition of the world" in which it is often and strongly deployed in the legitimization of political projects.

Keywords: tangible and intangible heritage, monument, lieux de mémoire, discourse.

Na początku XXI wieku wszechobecność dziedzictwa jest faktem. Spotkać je można zarówno w analitycznym języku nauki, jak i w życiu codziennym. Poza uniwersytetem odwołują się do niego jednostki i całe wspólnoty, które nawiązują relacje z wyselekcjonowaną, sklasyfikowaną, zrekonstruowaną i w określony sposób waloryzowaną przeszłością. Znaczący jest więc fakt, że dziedzictwo nie zostało zamknięte $\mathrm{w}$ analitycznym języku uniwersytetu, ale wyszło z jego ograniczeń i na stałe zagościło w społecznym sposobie opisywania przeszłości i budowania

${ }^{1}$ Niektóre myśli zawarte w tym tekście są rozwinięte w: K. Kowalski, O istocie dziedzictwa europejskiego - rozważania, Kraków 2013. 
z nią relacji. Choć jeszcze niedawno występowało wyłącznie w hermetycznym języku historii sztuki i konserwacji, dziś sięgają po nie inne nauki.

Innymi słowy, dziedzictwo odniosło sukces wewnątrz akademickiego dyskursu o przeszłości, gdyż tego pojęcia używają obecnie historia, socjologia, antropologia i etnografia, historia sztuki i konserwacja, nie wspominając o prawie i administracji, zarządzaniu czy ekonomii. To wyraz poszerzania się zakresu semantycznego dziedzictwa, które ponadto skutecznie zagospodarowuje tę część języka codziennego, która odnosi się do przeszłości. W konsekwencji poza historykami, socjologami, antropologami, etnografami, historykami sztuki, konserwatorami i muzealnikami pojęcia dziedzictwa z powodzeniem używają dziś prawnicy, administratorzy, menedżerowie, animatorzy kultury i „zwykli” amatorzy przeszłości.

Niniejszy tekst wskazuje kilka źródeł dzisiejszej definicji dziedzictwa (por. Harrison 2013; Macdonald 2013), wyrastającej z (1) zabytku z jego „rozszerzeniem”, (2) dóbr kultury i wymiany symbolicznej, (3) społecznie usankcjonowanej formy pamięci, tj. z miejsc pamięci (fr. lieu de memoire). Ostatnia część tekstu odsyła do tych teorii, które w znaczący sposób wpłynęły na ujmowanie dziedzictwa jako (4) ponowoczesnego produktu dyskursu, w którym nie tyle ważna jest „prawda (o) przeszłości”, ile społeczne sposoby jej wytwarzania i interpretacji.

\section{Dziedzictwo jako zmienny w czasie obraz przeszłości}

Gregory J. Ashworth pisał, że „[d]ziedzictwem jest wszystko to, co współcześni wybierają z przeszłości, jaką sami wykreowali na użytek czasów obecnych lub w celu przekazania potomnym. Dziedzictwo to proces, a nie typ zasobów. (...) Nie ma jednak z góry określonego stanu końcowego, a jego [dziedzictwa] cele mogą być współcześnie wielorakie i zmienne" (Ashworth 2007: 32-33). W podobny sposób dziedzictwo definiował Erdösi Péter, gdy formułował myśl, że: „[n] a potrzeby analizy kultur współczesnych lepiej jest (...) pojmować dziedzictwo jako konstrukt, artefakt, zmaterializowany obraz przeszłości tworzony w procesie nadawania statusu dziedzictwa, w którym jego twórcy mogą wyrazić swe związki z przeszłością, swą tożsamość i zrealizować własne teraźniejsze cele. Jest to wygodne również $\mathrm{z}$ analitycznego punktu widzenia, gdyż ułatwia usystematyzowanie różnych poziomów budowania dziedzictwa (globalnego, europejskiego, regionalnego, lokalnego), z ich uczestnikami, zbiorem obiektów, dyskursami, docelowymi grupami ludności, zakresami kompetencji, instytucjami i budżetami” (Erdösi 2007: 88-89). Analogicznie twierdził Sebastian Schröder-Esch, gdy pisał, że „(...) 'dziedzictwo' to (...) współczesny konstrukt społeczny, przypisywany w ciągłym procesie przemian wciąż nowym zjawiskom. Przy takim założeniu zabytek jest miejscem, gdzie dziedzictwo jako znaczenie jest rzutowane na artefakty materialne i w nie wplatane. Innymi słowy, zabytki symbolizują i wyrażają te aspekty przeszłości, które przez społeczeństwo uważane są za dziedzictwo" (Schröder-Esch 2007: 281). 
W tym samym tomie znaleźć można dwie podobne definicje dziedzictwa. Z kolei na gruncie refleksji francuskiej Dominique Poulot pisał, że „dziedzictwo nie jest przeszłością jako taką", ponieważ wyraża dzisiejsze tożsamości i utwierdza współczesne społecznie podzielane wartości. Innymi słowy, jest dziedzictwo współcześnie dokonywanym wyborem uwzględniającym cele, jakie teraźniejszość stawia przed przeszłością. Ponadto $\mathrm{w}$ ramach dziedzictwa dochodzi do celebrowania uczuć i budowania emocjonalnych obrazów przeszłości, co w praktyce może oznaczać przeciwstawienie się prawdzie historycznej. „Historia tak często wydaje się «martwa», gdy tymczasem dziedzictwo, przeciwnie, jest «żywe» dzięki wyznaniom wiary i wszelakim formom społecznego upamiętniania, które wokół niego się pojawiają" (Poulot 2006: 3). Parze przeciwieństw historia-pamięć (Nora 1984; 1986, 1992; por. Le Goff 2007) odpowiada tu inna para historia-dziedzictwo (por. Lowenthal 1998a), do której tak chętnie odwołuje się Poulot.

Uwikłanie dziedzictwa we współczesne cele powoduje jego swoistą koniunkturalność i efemeryczność oraz - ostatecznie - zmienność. Procesy budowania kanonów dziedzictwa nigdy się nie kończą, pewne elementy z nich są wykluczane, inne zaś korzystają z aktualnej przychylności i są do dziedzictw włączane. Niemniej ani wykluczenie, ani włączenie nie są jednak ostateczne, a przepływy między kanonem a „apokryfami” są możliwe. W konsekwencji historia dziedzictwa to ciąg konsekutywnie następujących po sobie aktów pamięci i zapomnienia (por. Ricoeur 1995; 2006) lub historia następujących po sobie strategii budowania obrazu przeszłości, które nie są ani uniwersalne, ani ponadczasowe, ale przynależą do świata Zachodu i powstały w XIX i XX wieku. Innymi słowy, Poulot pisał, że „[o]brazy przeszłości - 'prawdziwe' lub 'fałszywe' - są z pokolenia na pokolenie przekazywane, wykorzystywane, deformowane, zapominane, a każdy z nich zakrywa poprzedni, absorbuje go, modyfikuje. Równocześnie temu procesowi towarzyszy zmiana definicji i znaczenia pojęcia 'wandalizmu'” (Poulot 2003: 30). Istotą dziedzictwa nie jest więc prawda historyczna, jak rozumieli ją pozytywistyczni historycy, ale społeczna użyteczność i performatywność pozwalająca „zapanować” nad przeszłością i wykorzystać ją zgodnie z dzisiejszymi celami.

Ponadto dziedzictwo czerpie siłę ze swoistej obietnicy, która dotyczy symbolicznej i praktycznej kontroli współcześnie dokonującej się w akcie „wynajdowania” dziedzictwa, będącej analogią do strategii „wynajdowania” tradycji (Hobsbawm, Ranger 2008; por. Szacki 2011). Wyraża się ona w wyborze, klasyfikacji, udostępnianiu i interpretacji materialnych i niematerialnych pozostałości przeszłości. Dziedzictwo nie jest jednak wyłącznie domeną ekspertów, którzy je „wynajdują", ale również publiczności, która owo „wynalezione” dziedzictwo odwiedza, alternatywnie interpretuje i w konsekwencji w ten sposób wpływa na jego znaczenie i wykorzystanie we własnej codzienności (Poulot 2006: 6; por. Certeau de 2008). We wszystkich tych perspektywach „wynajdowania” i interpretacji dziedzictwo pozostaje w silnej relacji z tożsamością, której jest wyrazem na poziomie indywidualnym, lokalnym, narodowym, europejskim i uniwersalnym. 


\section{Zabytek a dziedzictwo}

Współczesne rozumienie dziedzictwa wyrasta z pojęcia zabytku. Jest on pierwszym ogniwem ewolucji, która rozpoczęła się konserwatorskimi teoriami Aloisa Riegla na początku XX wieku (patrz: Karta Ateńska 1931 i Karta Wenecka 1964) i którą wieńczą współczesne konwencje UNESCO i Rady Europy, uznające za dziedzictwo środowisko naturalne (patrz: Konwencja w sprawie ochrony światowego dziedzictwa kulturalnego i naturalnego 1972), pejzaż (patrz: Europejska konwencja krajobrazowa 2000) niematerialny wymiar kultury (patrz: Konwencja o ochronie niematerialnego dziedzictwa kulturowego 2003). Dzisiejsze rozwiązania uwzględniają ponadto rolę, jaką ono odgrywa w społeczności (patrz: Ramowa konwencja Rady Europy dotycząca wartości dziedzictwa kulturowego dla społeczeństwa 2005) oraz konieczność ochrony genius loci (patrz: Deklaracja w sprawie zachowania genius loci 2008).

Alois Riegl pisał, że: „w najstarszym i najpierwotniejszym znaczeniu przez 'pomnik' [zabytek, znak pamięci] rozumie się jakieś dzieło ludzkiej ręki, wzniesione dla określonego celu po to, aby w sposób żywotny i zawsze aktualny zachować poszczególne ludzkie czyny i losy w świadomości późniejszych pokoleń" (Riegl 2002: 27). Istotą zabytku jest więc upamiętnienie odcinka czasu historycznego, a „[h]istorycznym nazywamy wszystko to, co było i czego dziś już nie ma” (Riegl 2002: 28).

W XX wieku, rozszerzając swój semantyczny zakres, zabytek przeszedł metamorfozę, której cztery wymiary wskazywała Nathalie Heinich - chronologiczny, topograficzny, klasyfikacyjny i teoretyczny (Heinich 2009: 17-21). Rozszerzenie chronologiczne osłabia wartość dawności, wzmacniając rolę teraźniejszości i uznając za dziedzictwo obiekty stosunkowo młode, niemal współczesne lub - zwyczajnie - współczesne. Dystans czasowy przestawał być warunkiem, jaki musiał spełniać obiekt, by uznano go za taki, który jest wart ochrony i przekazania potomnym. Pod względem topograficznym zabytek, stając się dziedzictwem, uwzględnił kontekst, środowisko, pejzaż, którego do tej pory ani konserwacja, ani ochrona nie obejmowały. Rozszerzenie trzecie - klasyfikacyjne - wyraża się w uznaniu za dziedzictwo nie tylko dzieł cieszących się prestiżem, ale również takich, które posiadają szczególną specyfikę, wyjątkowość, niepowtarzalność (tzw. nowe dziedzictwo, czyli wnętrza sklepów, dworce, zakłady przemysłowe itp.). Ponadto $\mathrm{w}$ wyniku tego rozszerzenia klasyfikacyjnego w obszarze dziedzictwa znalazło się dziedzictwo niematerialne, dziedzictwo industrialne czy powstające od lat 70. XX wieku ekomuzea i wcześniejsze skanseny.

Ostatni wymiar metamorfozy, która z zabytku uczyniła dziedzictwo, ma charakter teoretyczny i dotyczy swoistej logiki patrymonialnej, gdyż uwaga przestała być skupiona na przedmiotach wyjątkowych, a zaczęła ogniskować się na eksponatach, które reprezentują całe serie identycznych obiektów. To odejście od unicum i waloryzowanie typicum. Heinich pisała, że „[w]artość przedmiotu nie 
leży już w jego rzadkości [niepowtarzalności, unikatowości], ale w fakcie, że ogniskują się w nim cechy właściwe dla całej kategorii" (Heinich 2009: 20)². I tak opisywany przez Heinich proces doprowadził do wyraźnego rozszerzenia pojęcia zabytku i ukonstytuowania się współczesnej definicji pojęcia dziedzictwa oraz nowych strategii konserwatorskich, które z natury rzeczy musiały się pojawić wokół nowych patrymonializowanych obiektów.

\section{Dobra i wymiana symboliczna}

Nathalie Heinich szczególną uwagę kieruje na istotę dóbr uznawanych za dziedzictwo (Heinich 2009). Czyniąc to, nawiązuje do spostrzeżeń Maurice’a Godeliera, który pisał, że istnieją trzy kategorie rzeczy - te, które można sprzedać, te, które należy ofiarować, oraz te, które należy zachować. Dziedzictwo odpowiada ostatniej grupie. W tym sensie, „[b]y społeczeństwo reprodukowało się, konieczne jest połączenie trzech baz z trzema zasadami. Należy dać pewne rzeczy, inne należy sprzedać lub przehandlować, inne jeszcze zawsze należy zachować. W naszych społeczeństwach, sprzedaż i kupno stały się dominującymi działaniami. Sprzedać, oznacza całkowicie oddzielić rzeczy od ludzi. Dać, oznacza zawsze zachować w rzeczy, która jest dana, coś z osoby, która daje. Zachować, oznacza nie oddzielić rzeczy od ludzi, ponieważ w tej jedności wyraża się tożsamość historyczna, którą należy przekazać (...). Ponieważ te trzy operacje - sprzedaży, darowania i zachowania - nie są tożsame, to przedmioty występują w trzech kontekstach: albo jako rzeczy zbywalne i zbyte (towary), albo jako rzeczy niezbywalne, ale jednak zbyte (dary), albo jako rzeczy niezbywalne i niezbyte (na przykład przedmioty święte, teksty praw)" (Godelier 2007: 87-88; por. Godelier 2010; Mauss 1973; Mauss 2005). Heinich twierdzi, idąc śladem Godeliera, iż dziedzictwo jest zlaicyzowaną wersją przedmiotów naznaczonych sacrum oraz że współczesny kult dziedzictwa można analizować jako skutek ,transferu sacrum, ponieważ przedmiot odziedziczony zajmuje w symbolicznym systemie współczesnych społeczeństw podlegających 'odczarowaniu' miejsce 'skarbu' religijnego (...)" (Heinich 2009: 29).

Sakralna natura dziedzictwa i jego kult we współczesnym świecie wiele wnosi do jego rozumienia (Choay 1984). Są to bowiem współczesne relikwie, regalia, skarby narodowe i ostatecznie obiekty troski administracyjnej i badań naukowych (Babelon, Chastel 1994). Jean-Pierre Babelon i André Chastel pisali, że dziedzictwo można rozpoznać w prosty sposób. Otóż jego utrata odczuwana jest jak złożona ofiara, ale - jednocześnie - konserwacja i ochrona dziedzictwa również wymagają wyrzeczeń, czyli wiąże się z nimi także ofiara (Babelon, Chastel 1994: 101).

${ }^{2}$ Warto nadmienić, że do podobnych wniosków doszła Cezaria Baudouin de Courtenay Ehrenkreutz Jędrzejewiczowa (Zakład Etnologii Uniwersytetu Stefana Batorego w Wilnie, „Balticoslavica” 1938, t. 1, s. 75-98). 


\section{Lieux de mémoire / miejsca pamięci}

$\mathrm{Na}$ początku lat 80 . XX wieku narodziły się lieux de mémoire, miejsca pamięci, których wielkim propagatorem był - i jest nadal - Pierre Nora (Nora 1984; 1986; 1992). To za ich pośrednictwem ciężar refleksji dotyczącej przeszłości przesunął się z faktów, wydarzeń, narracji i reprezentacji na proces społecznego konstruowania historii. Dzięki lieux de mémoire - jak pisała Ewa Domańska - historia włączyła w swój zasięg pamięć i doświadczenie historyczne (Domańska 2004: 9; por. LaCapra 2002). Owo przesunięcie akcentów z uniwersyteckiej narracji o przeszłości na pozaakademickie strategie budowania obrazu przeszłości i doświadczania jej otwarło drogę do współczesnego pojmowania dziedzictwa, które demokratyzuje dostęp do zasobów przeszłości i jej interpretacji oraz użycia.

Istotą owej redefinicji historii była między innymi rehabilitacja pamięci jako przedmiotu refleksji historycznej. Nie była bowiem pamięć do tego momentu przedmiotem zainteresowania historyków. Gdy tymczasem - jak pisał Jacques Le Goff - „[p]amięć jest zasadniczym elementem tego, co od niedawna nazywa się tożsamością indywidualną i zbiorową. Poszukiwanie tożsamości, z zapałem i obawą, jest jednym z podstawowych działań dzisiejszych jednostek i społeczeństw. Pamięć zbiorowa jest jednak nie tylko zdobyczą, lecz także narzędziem i celem władzy. Istnieją społeczeństwa, których pamięć społeczna jest przede wszystkim ustna lub które właśnie tworzą pamięć zbiorową pisaną, pozwalającą lepiej uchwycić walkę o przewagę wspomnienia i tradycji; walkę, która polega na manipulowaniu przeszłością" (Le Goff 2007: 155). Z przedmiotu niedostrzeganego stała się pamięć przedmiotem poznania historycznego, rozróżnienia kultur (względem różnych stosowanych przez nie strategii upamiętniania przeszłości) i krytyki, wynikającej z obawy o jej zręczną manipulację (por. Cassirer 2006: 307-328).

Le Goff, definiując obszar nowych zainteresowań historii - pamięć właśnie pisał o „badaniu, ocaleniu i docenieniu pamięci zbiorowej” nie w jej wydarzeniowym ujęciu, ale $\mathrm{w}$ długim trwaniu. Tym samym wskazywał potrzebę „przemiany spojrzenia historycznego", gdyż śladów owej pamięci szukał nie w klasycznych źródłach, a w „słowach, wizerunkach, gestach, rytuałach i świętach” (Le Goff 2007: 152). Takie rozłożenie akcentów badawczych pozwoliło pamięci społecznej zaistnieć jako przedmiot badania historycznego (patrz: Daileader, Whalen 2010).

Konsekwencją uwzględnienia pamięci w badaniach historycznych było - właśnie - powstanie lieux de mémoire. Nora nie ogranicza ich rozumienia do topograficznego wymiaru i twierdzi, że są nimi materialne lub idealne (niematerialne) całości znaczące, które wskutek zaangażowania jednostek i wspólnot lub wskutek pracy czasu stały się cząstką pamiętanego i przekazywanego dziedzictwa danej wspólnoty (Nora 1986: 22-26). Odwołując się do stwierdzeń Nory, na gruncie polskiej refleksji o miejscach pamięci Kornelia Kończal pisała tak: „(...) są [nimi] zatem fenomeny obecne w pamięci zbiorowej, budujące tożsamość grupy i będące tym samym punktami kolektywnych autodefinicji” (Kończal 2009: 211). Innymi 
słowy, miejsca pamięci rozumieć należy jako metaforę i nie skupiać się na topograficznej sugestii, gdyż są one silnie nasycone „metaforami, skojarzeniami i alegoriami".

W innym miejscu Kończal, pisząc o miejscach pamięci, przywoływała twierdzenia François Étienne i Hagen Schutze, że:

[p]onieważ słowo 'miejsce pamięci' prowadzić może do nieporozumień, należy przypomnieć, że nie chodzi tu o filozoficzno-analityczne znaczenie tego terminu, lecz o metaforę. (...) Miejscami pamięci mogą być zarówno zjawiska natury materialnej, jak i niematerialnej, należą do nich zarówno realne, jak i mityczne postaci, wydarzenia, budynki i pomniki, instytucje i pojęcia, książki i dzieła sztuki - można by zatem posłużyć się dzisiejszym terminem 'ikona'. [Miejsca pamięci to - dopisek Kornelia Kończal] długotrwałe, konstytutywne dla wielu pokoleń punkty krystalizacyjne pamięci zbiorowej i tożsamości, które stanowiąc część zwyczajów społecznych, kulturowych i politycznych, zmieniają się w zależności od tego, jak zmienia się ich postrzeganie, przyswajanie, używanie i transponowanie. [Chodzi zatem o miejsce - dopisek Kornelia Kończal] jako metaforę, jako topos w dosłownym tego słowa znaczeniu. Miejsce nie jest przy tym postrzegane jako skończona całość; wręcz przeciwnie: stanowi ono element realnej, społecznej, politycznej, kulturowej lub wyobrażonej przestrzeni" (Étienne, Schutze 2001: 17f; cyt. za: Kończal 2009: 214-215).

Warto zauważyć, że koncepcja miejsc pamięci wyrasta z opozycji, w jakiej pozostają historia i pamięć, obie rozumiane jako odmienne strategie budowania obrazu przeszłości. Pierwsza jest akademickim - choćby iluzorycznym - dążeniem do prawdy. Druga zaś - pamięć - twierdzi, że prawd jest wiele i że dodatkowo są one zmienne w czasie (patrz: Nora 2009; por. Szacka 2005: 17-30; Szpociński 1983: 129-146). Ta opozycja przypomina inne zestawienie, a mianowicie to, które interesuje nas tu bardziej. Mam na myśli historię i dziedzictwo. W tej parze przeciwieństw dziedzictwo, wstawione w miejsce pamięci, nie dba o prawdę historyczną, choć na ustaleniach historii się opiera. Bez historii obejść się nie może, choć wykorzystując ustalenia historii, dziedzictwo zakłada milcząco, że prawd jest wiele (tyle, ilu konsumentów przeszłości), że każdy ma prawo do swojej mikronarracji o przeszłości i wynikającej z niej „mikroprawdy”. Owa patrymonialna prawda jest produktem dyskursu, który ją kreuje.

\section{Dziedzictwo jako rezultat ponowoczesności, dyskursów i wielości prawd}

W obszarze refleksji nad przeszłością dziedzictwo jest konsekwencją ponowoczesności wyrażającej się w nauce odejściem od wielkich narracji, zarzuceniem jednego światopoglądu naukowego i uznaniem równoważności prawd, które kryją się za zrehabilitowanymi mikronarracjami (patrz Bauman 2004: 903-904). Ponowoczesną podejrzliwość wobec metanarracji Lyotard diagnozował następująco: „Skrajnie upraszczając, za 'postmodernistyczną' uznajemy nieufność w sto- 
sunku do metanarracji. (...) Funkcja narracyjna traci swoje funktory: wielkiego bohatera, wielkie zagrożenia, wielkie przedsięwzięcia i wielki cel. Rozpryskuje się na ulotne zjawiska językowych elementów narracyjnych (...) z których każdy niesie z sobą pragmatyczne wartości sui generis. Wszyscy żyjemy na skrzyżowaniu wielu z nich. Nie ma takiej konieczności, żebyśmy tworzyli stałe kombinacje językowe, a właściwości tych, które tworzymy, niekoniecznie nadają się do przekazania" (Lyotard 1997: 20) Ten fragment zwraca uwagę nie tylko na brak zaufania do wielkich opowieści, ale również - a może przede wszystkim - na performatywną funkcję języka, pragmatyzm i odczarowanie współczesnego świata (Gauchet 1985), w którym grands récits (fr.) / grand narratives (ang.) zostały zastąpione grami językowymi o mocno lokalnym, arbitralnym, subiektywnym charakterze. Innymi słowy, obecnie, w epoce ponowoczesności każdy ma prawo do swojej małej opowieści, do swojej własnej - nawet subiektywnej - prawdy; każdy ma prawo do dziedzictwa na własną miarę oraz wedle własnych potrzeb i realizowanych celów (Kowalska 1997: 5-17).

Innymi słowy, współczesny zakres semantyczny dziedzictwa i towarzyszące mu praktyki dyskursywne, zarówno te akademickie, jak i pozaakademickie, są logiczną konsekwencją odejścia od monolitycznego sposobu interpretacji przeszłości (dziedzictwo narodowe) na rzecz heterogeniczności dyskursów o przeszłości. Ponowoczesność w patrymonialnej odsłonie oznacza udzielenie głosu tym, którzy do tej pory nie byli uwzględniani, słyszalni ani słuchani (społeczności lokalne, mniejszości narodowe, etniczne, seksualne etc.). Gdy uwzględnić to przesunięcie akcentów (od monolitu do wielogłosowości) i spojrzeć na dziedzictwo jak na jeden z praktycznych rezultatów postmodernistycznej ewolucji w zakresie klasyfikacji, interpretacji i wykorzystania przeszłości, to okazuje się, że w epoce ponowoczesnej następuje wyraźne rozproszenie kontroli nad przeszłością i jej interpretacjami. Do tej pory wypowiadali się o niej akademiccy eksperci, często centralnego szczebla, równie często arbitralnie uznając - bez konsultacji z lokalnymi społecznościami konkretne obiekty za dziedzictwo warte ochrony i przekazania następnym pokoleniom. Dziś widać, że postmodernizm zdemokratyzował nie tylko dostęp do świadectw przeszłości, ale również do ich interpretacji i wykorzystania.

Dziedzictwo jest najnowszym wyrazem dyskursywnej kontroli, którą wobec przeszłości stosują ponowocześni „profesjonaliści od przeszłości”, pracujący na uniwersytetach i poza nimi. Co więcej, za ową kontrolą postępuje wielość dyskursywnie konstruowanych prawd, które są na ludzką miarę i nie roszczą sobie prawa do uniwersalności. I w tym kontekście zasadnie można zastanawiać się nad rolą, jaką w całości patrymonialnego przedsięwzięcia odgrywa prawda, która byłaby ponowoczesnym odpowiednikiem „wcześniejszej” prawdy, którą spodziewała się odnaleźć nowoczesna, pozytywistycznie uprawiana historia.

Można tu wyrazić opinię, że prawda i autentyczność są mocno dyskusyjnymi kategoriami w kontekście refleksji nad dziedzictwem, gdyż, „[p]rawda pojmowana klasycznie jako zgodność sądu z rzeczywistością jest fikcją, tak jak fikcją jest 
idea jednej rzeczywistości, której esencjonalne cechy czekają tylko na odkrycie. Wielości kulturowo kreowanych rzeczywistości, będących przedmiotem poznania, towarzyszy wielość prawd" (Szahaj 1996: 163). Dodać można, przywołując dyskursywne rozważania Michela Foucaulta, że „[p]rawda jest rzeczą z tego świata: jest ona tworzona jedynie na mocy wielostronnych form przymusu. I to wytwarza regularne efekty władzy. Każde społeczeństwo posiada swój rząd prawdy, swoją generalną politykę prawdy; to znaczy typy dyskursu, które akceptuje i które działają jako prawdziwe (...) Prawda ma być rozumiana jako system uporządkowanych procedur na rzecz wytwarzania, regulowania, dystrybucji, cyrkulacji oraz działania twierdzeń" (Foucault 1980: 131-132, cyt. za: Flis 2004: 21).

Aplikacja koncepcji Foucaulta do refleksji nad dziedzictwem prowadzi do teorii, które uznają je za produkt dyskursu. Co więcej nawet, Laurajane Smith, której prace wytyczyły nowe kierunki w aplikacji teorii dyskursywnych do badań nad dziedzictwem, konstatuje, że w przeciwieństwie do dziedzictwa - które nie istnieje - funkcjonują za to społeczne sposoby jego wytwarzania, determinujące, jak myślimy, mówimy i piszemy o dziedzictwie (Smith 2006: 11). Uznaje ona, że od tych społecznie usankcjonowanych zasad nie ma ucieczki, choć - co w pewien sposób paradoksalne - nie są one ani w czasie niezmienne, ani nie mają uniwersalnego charakteru. Raz przyjęty obraz przeszłości, którego czujemy się spadkobiercami lub który odrzucamy, choć bardzo opornie poddaje się zmianom, to jednak z biegiem czasu im ulega.

\section{Podsumowanie}

Dzisiejsze pojęcie dziedzictwa jest wynikiem ewolucji, której uległy pojęcia naukowe stosowane do opisu przeszłości i budowania z nią relacji. Na szczególną pod tym względem uwagę zasługują zabytki, dobra kultury, pamięć i miejsca pamięci (por. Kowalski 2013). Sądzę jednak, że owa ewolucja konceptualna wewnątrz konkretnych nauk i samego uniwersytetu nie była conditio sine qua non obserwowanego współcześnie sukcesu dziedzictwa. Otóż, nie tylko nauki o przeszłości i stosowane przez nie pojęcia uległy przemianie, synergicznie generując współczesny zakres tego pojęcia i w zasadzie odbierając mu wszelką precyzję, jaką posiadało ono przed stu laty (Nora 2010). Ale - co poniekąd oczywiste - świat się zmienił, a wraz z nastaniem ponowoczesności i zastąpieniem wielkich opowieści ich lokalnymi i często indywidualnymi odpowiednikami rola prawdy historycznej i autentyzmu substancji materialnej została osłabiona. Dziedzictwo inaczej rozłożyło akcenty, dopuszczając wielość interpretacji oraz odchodząc od wyłączności, którą utracili akademiccy eksperci pracujący na materii przeszłości.

Uwzględniając ów akademicki i społeczny potencjał dziedzictwa, warto zauważyć, że jego rozkwit w Europie Środkowej zaczyna się na początku lat 90. XX wieku. Wtedy, po memory turn i równolegle do memory boom zaczęlo ono święcić trium- 
fy. Upadek Bloku Wschodniego oraz przystąpienie wielu krajów Europy Środkowej i Wschodniej do Unii Europejskiej (2004) wytworzyły kontekst, w który dziedzictwo wpisało się znakomicie. Wiele zawdzięczając francuskiej i anglosaskiej tradycji naukowej, stało się narzędziem symbolicznego zjednoczenia karolińskiej części Europy z jej środkowoeuropejskim i wschodnioeuropejskim odpowiednikiem. Ponadto rola konceptualnego spoiwa w budowaniu wspólnego obrazu Europy, który miał wychodzić poza zimnowojenny podział wprowadzony żelazną kurtyną, była - i nadal jest - wyjątkowo istotna.

Po wielkim rozszerzeniu UE (2004) praktyczna aplikacja tego pojęcia nie była wolna od politycznych aliansów i realizowała wartości, na których zbudowano UE. W tym jednak wyrażał się konsensualny/pojednawczy/europejski wymiar tego pojęcia. Dziedzictwo miało łączyć i budować europejskie mosty, gdyż narodowe historie i indywidualne pamięci dzieliły. W tym tkwiła - i nadal zresztą tkwi - wielka moralna siła tego pojęcia.

Tymczasem z dziedzictwem wiąże się wspomniana obawa przed takim jego (nad)użyciem, które co prawda odpowie na współcześnie wygenerowaną potrzebę dawności, ale zrealizuje takie cele i będzie inkarnacją takich wartości, które zaprzeczą dotychczas obserwowanej tendencji europeizacyjnej w obszarze praktycznej aplikacji tego pojęcia (por. Kowalski, Törnquist-Plewa (red.) 2016). Pamiętać bowiem należy, że dziedzictwo nie jest dane raz na zawsze i że tę samą przeszłość formatować mogą kolejni „rzemieślnicy od przeszłości”. Ich intronizacja dokonywać się może i szybko, i skutecznie, a ich działania podyktowane być mogą doraźnymi indywidualnymi i wspólnotowymi celami. W konsekwencji to samo pojęcie - dziedzictwo właśnie - służyć może wyciszeniu, zapomnieniu, pominięciu, wykluczeniu konkretnego dziedzictwa i jego dziedziców. Ten fakt jest tym groźniejszy, że dziedzictwo niekoniecznie opiera się na prawdzie tout court, ale na często stosowanej symulacji przeszłości (Baudrillard 2005; 2006), dla której prawda nie jest wartością centralną (Lowenthal 1998a, b). Przeciwnie nawet. Jest dziedzictwo królestwem wzbudzanych emocji i postprawdy. Ten fakt jest konsekwencją postmodernistycznej utraty wiary $\mathrm{w}$ jedną prawdę i przyzwolenia na współistnienie wielu mikronarracji, w tym takich, które przeszłość mogą zafałszowywać. Innymi słowy, polityczne zaangażowanie tego pojęcia obserwowalne od lat 90. XX wieku w Europie Środkowej i Wschodniej, które było przyczyną jego niekwestionowanego sukcesu, dziś może okazać się jego przekleństwem i zaprzeczeniem.

Konkludując, chcę wyrazić przekonanie, że ze względu na plastyczność i podatność dziedzictwa na polityczne alianse, w które ono z dużą łatwością wchodzi, stać się może przedmiotem i narzędziem historycznej inżynierii, której dopuszczać się mogą kolejni „rzemieślnicy od przeszłości”. I tego we współczesnej Europie obawiać się należy najbardziej (Cassirer 2006). 


\section{Bibliografia}

Ashworth G.J.

2007 Sfragmentaryzowane dziedzictwo: sfragmentaryzowany instrument sfragmentaryzowanej polityki, w: Dziedzictwo kulturowe w XXI wieku. Szanse i wyzwania, red. M. Murzyn, J. Purchla, Kraków, s. 29-42.

Babelon J.-P., Chastel A.

1994 La notion de patrimoine, Paris.

Baudrillard J.

2005 Symulakry i symulacja, przeł. S. Królak, Warszawa.

Baudrillard J.

2006 Społeczeństwo konsumpcyjne. Jego mity i struktury, przeł. S. Królak, Warszawa.

Bauman Z.

2004 Ponowoczesność, w: Słownik społeczny, red. B. Szlachta, Kraków, s. 903-904.

Cassirer E.

2006 Mit państwa, przeł. A. Staniewska, Warszawa.

Certeau de $\mathrm{M}$.

2008 Wynaleźć codzienność. Sztuki działania, przeł. K. Thiel-Jańczuk, Kraków.

Choay F.

1984 A propos de culte et de monuments (wstęp), w: A. Riegl, Le culte moderne des monuments. Son essence et sa genèse, Paris, s. 7-20.

Choay $\mathrm{F}$.

2009 Le patrimoine en question. Anthologie pour un combat, Paris.

Daileader Ph., Whalen Ph. (red.)

2010 French Historians 1900-2000. New Historical Writing in Twentieth-Century Europe, Oxford.

Domańska E.

2004 Miejsce Franka Ankersmita w narratywistycznej filozofii historii (wstęp), w: F.R. Ankersmit, Narracja, reprezentacja, doświadczenie: studia z teorii historiografii, Kraków, s. 5-27.

Erdösi P.

2007 Ku Wyspom Dziedzictwa na Morzu Środkowoeuropejskim, w: Dziedzictwo kulturowe w XXI wieku. Szanse i wyzwania, red. M. Murzyn, J. Purchla, Kraków, s. 87-96.

Étienne F., Schutze H. (red.)

2001 Deutsche Erinnerungsorte, München.

Flis M.

2004 Etyczny wymiar tożsamości kulturowej, Kraków.

Foucault M.

1980 Power/Knowledge. Selected Interviews and other Writings 1972-1977, New York. Gauchet M.

1985 Le désenchantement du monde. Une histoire politique de la religion, Paris.

Godelier M.

2007 Au fondement des sociétés humaines. Ce que nous apprend l'anthropologie, Paris.

Godelier M.

2010 Zagadka daru, przeł. M. Höffner, Kraków. 
Harrison R.

2013 Heritage. Critical Approaches, Milton Park - Abingdon - New York.

Heinich N.

2009 La fabrique du patrimoine. De la cathédrale à la petite cuillière, Paris.

Hobsbawm E., Ranger T. (red.),

2008 Tradycja wynaleziona, przeł. M. Godyń, F. Godyń, Kraków.

Kończal K.

2009 Bliskie spotkania z historia drugiego stopnia, w: Pamięć zbiorowa jako czynnik integracji i źródło konfliktów, red. A. Szpociński, Warszawa, s. 214-215.

Kowalska M.

1997 Mała opowieść tłumacza, w: J.-F. Lyotard, Kondycja ponowoczesna. Raport o stanie wiedzy, Warszawa, 1997, s. 5-17.

Kowalski K.

2013 O istocie dziedzictwa europejskiego - rozważania, Kraków.

Kowalski K., Törnquist-Plewa B. (red.),

2016 The Europeanization of Heritage and Memories in Poland and Sweden, Cracow.

Krawczyk J.

2008 Teoria Aloisa Riegla i jej polska recepcja a problemy współczesnego konserwatorstwa, w: Współczesne problemy teorii konserwatorskiej w Polsce, red. B. Szmygin, Warszawa-Lublin, s. 63-74.

Krawczyk J.

2009 Kompromis i metoda - wybrane aspekty teorii konserwatorskich Aloisa Riegla i Cesare Brandiego, „Ochrona Zabytków”, nr 2(245), LXII, s. 65-74.

LaCapra D.

2002 Psychoanaliza, pamięć i zwrot etyczny, przeł. M. Zapędowska, w: Pamięć, etyka $i$ historia. Anglo-amerykańska teoria historiografii lat dziewięćdziesiątych (Antologia przekładów), red. E. Domańska, Poznań, s. 127-162.

Le Goff J.

2007 Historia i pamięć, przeł. A. Gronowska, J. Stryjczyk, Warszawa.

Le Goff J., Nora P. (red.)

1974 Faire de l'histoire, Paris.

Lowenthal D.

1998a La fabrication d'un héritage, w: Patrimoine et modernité, red. D. Poulot, Paris, s. $107-127$.

Lowenthal D.

1998b The Heritage Crusade and the Spoils of History, Cambridge-New York.

Lyotard J.-F.

1997 Kondycja ponowoczesna. Raport o stanie wiedzy, przeł. M. Kowalska, J. Migasiński, Warszawa.

Macdonald S.

2013, Memorylands: Heritage and Identity in Europe Today, London-New York.

Mauss M.

1973 Szkic o darze [w:] Mauss M., Antropologia i socjologia, przeł. M. Król, K. Pomian, J. Szacki, wstęp C. Lévi-Strauss, Warszawa, s. 211-331.

Mauss M., Hubert H.

2005 Esej o naturze i funkcji ofiary, przeł. L. Trzcionkowski, Kraków. 


\section{Nora P.}

1974 Mémoire collective [w:] Faire de l'histoire, red. J. Le Goff, P. Nora, Paris, s. 398-401. Nora P. (red.)

1984 Les lieux de mémoire, t. 1: La République, Paris.

1986 Les lieux de mémoire, t. 2: La Nation, Paris.

1992 Les lieux de mémoire, t. 3: Les France, Paris.

Nora P.

2009 Między pamięcia i historią: Les lieux de mémoire, „Tytuł roboczy: Archiwum”, nr 2, s. $4-12$.

Nora $P$.

2010 Dziedzictwo, „Przegląd Polityczny”, nr 103/104, s. 234-236.

Poulot D.

2003 La naissance d'une tradition européenne du patrimoine / The Birth of a European Heritage Tradition, w: Regards croisés sur le patrimoine dans le monde à l'aube du XXIe siècle, red. M. Gravari-Barbas, S. Guichard-Anguis, Paris, s. 29-44.

Poulot D.

2006 Une historie du patrimoine en Occident, XVIIIe-XXIe siècle. Du monument aux valeurs, Paris.

Ricoeur P.

1985 Egzystencja i hermeneutyka, wybór i oprac. S. Cichowicz, przeł. E. Bieńkowska $\mathrm{i}$ in., Warszawa.

Ricoeur P.

1995 Pamięć - zapomnienie - historia, w: Tożsamość w czasach zmiany. Rozmowy w Castel Gandolfo, red. K. Michalski, Kraków, s. 22-43.

Ricoeur P.

2006 Pamięć, historia, zapomnienie, przeł. J. Margański, Kraków.

Riegl A.

1903 Der Moderne Denkmalkultus. Sein Wesen und seine Entstehung, Wien-Leipzig.

Riegl A.

2002 Nowoczesny kult zabytków. Jego istota i powstanie, przeł. R. Kasperowicz, w: Alois

Riegl, Georg Dehio i kult zabytków, red. J. Krawczyk, Warszawa, s. 27-70.

Schröder-Esch S.

2007 Znaczenie dziedzictwa i nowych mediów dla rozwoju regionalnego - doświadczenia europejskiego programu HERMES, w: Dziedzictwo kulturowe w XXI wieku. Szanse i wyzwania, red. M. Murzyn, J. Purchla, Kraków, s. 277-297.

Smith L.

2006 Uses of Heritage, London.

Szacka B.

2005 Pamięć zbiorowa, w: Wobec przeszłości. Pamięć przeszłości jako element kultury współczesnej, red. A. Szpociński, Warszawa, s. 17-30.

Szacki J.

2011 [1971] Tradycja, Warszawa.

Szahaj A.

1996 Ironia i miłość. Neopragmatyzm Richarda Rorty’ego w kontekście sporu o postmodernizm, Wrocław.

Szpociński A.

1983 Kanon historyczny, „Studia Socjologiczne”, nr 4, s. 129-146. 
Szpociński A.

2008 Miejsca pamięci, „Teksty Drugie”, nr 4, s. 11-20.

Deklaracje, karty, konwencje, ustawy:

Deklaracja w sprawie zachowania genius loci (ducha miejsca), Quebec 2008.

Europejska konwencja krajobrazowa, Florencja 2000.

Karta Ateńska, 1931.

Karta Wenecka, 1964.

Konwencja w sprawie ochrony światowego dziedzictwa kulturalnego i naturalnego, Paryż 1972.

Konwencja o ochronie niematerialnego dziedzictwa kulturowego, Paryż 2003.

Ramowa konwencja Rady Europy dotycząca wartości dziedzictwa kulturowego dla społeczeństwa, Faro 2005.

Ustawa o ochronie zabytków i opiece nad zabytkami, Dziennik Ustaw, nr 162 poz. 1568, 2003. 